\title{
A Review of Social Safety Nets Programs for Women in Bangladesh: Issue and Challenges
}

\author{
Mohammad Abdul Hannan Pradhan*, Sabiha Afrin \\ Department of Economics, Shahjalal University of Science and Technology, Sylhet-3114, Bangladesh
}

Copyright (C) 2015 Horizon Research Publishing All rights reserved.

\begin{abstract}
A large scale social safety net (SSN) programs with grants cash or in-kind for targeted people such as children, elderly, and women have been implementing by the government and non-government organization in Bangladesh. Among the other group of people, women are considered more vulnerable due to social and economic point of views, particularly rural and elderly women. To protect them, government has taken some special SSN program like old age allowance, widow and destitute allowance, allowance for lactating poor mothers. Current demographic trend shows that number of women in different age group increases, especially elderly women. This article focuses on whether the currently operated programs by the government are sufficient in terms of benefit and number of qualified women in different age group for the benefit. In view of existing literature and documents, it is found that a small number of qualified women for the benefit are getting government provided benefits. Besides, amount of receiving benefit is also negligible taking into account the living expenses. For social and economic stability, government needs to extend the benefits amount and number of beneficiaries.
\end{abstract}

Keywords Social Safety Nets, Elderly, Women, Allowance

JEL: I38, J11

\section{Introduction}

Bangladesh is the $8^{\text {th }}$ largest populous country in the world with total population of about 150 million. According to the number of population, Bangladesh is ahead of Mexico, Japan, and Russia. The current demographic trend shows that proportion of female in the different age groups is increasing with other developing Asian countries like Thailand. In addition, women's life expectancy is becoming longer than men [1]. From the last two decades, enrolment rate in different education stages has been increasing gradually. As a result, literacy rate and employment in formal private sector are also increasing on an average. On the other hand, women, especially in rural, still are facing discrimination in all spheres of life. Parents and relatives are not celebrating the birth of a female child in the rural area. From the childhood, they are given a moral consciousness to sacrifice all for male [2]. Even in the same family, food, clothing, schooling, and other opportunities are offered to male children first. If the household have sufficient affordability, next priority is given to the female children for that opportunity [3]. When they are grown up at five or more years, they are involved in looking after their younger and other household activities. Poor families have no encouraged sending their female children to school. After marriage, they start to serve to their husband's family. In their husband's family, they also receive less household resources for their livelihood and other expenses than male [2,3]. However, most of the rural women are above all dependent on male for their basic survival. They are not involved in income generating activities. If they are involved, generally that is controlled by their husband. Therefore, for their livelihood they have to depend on parents or husband or male children.

Divorced and discarded by the husband is a common phenomenon among the poor in the rural area. Divorced, discarded, and single women have no social position. In the early stage they try to get second marriage. Numbers of widowed are increasing due to marry men older than themselves [1]. But after a certain age it is difficult for widowed, discarded or divorced women to get remarriage. Moreover, they become a burden for the family. If they remain unmarried, they have to live under a guardian. Jahan [2] mentioned that before marriage their father is their guardian, after marriage their husband is their guardian, after husband's death, their child is their guardian. Rahman et al. [4] mentioned that traditional joint family is breaking down rapidly and nuclear family is becoming a common family structure in urban and rural area. As a result, when their children after getting marriage left them alone in the rural area in their elderly, they have non to take care of them, nothing for their livelihood.

Though Bangladesh has made a remarkable progress in improving its social indicators in many aspects such as decreasing infant mortality rate and the rate of population growth, increasing school attendance, female particularly 
rural female are still more vulnerable and poor. According to HIES 2010 , about $14.6 \%$ and $26.6 \%$ people are hardcore poor and poor who are female headed, respectively. In addition, among the poor about $33.9 \%$ is widowed or divorced [5]. Moreover, low per capita income, social discrepancy to women and corresponding size of vulnerable people in the form of shocks such as flood, illness is very large. So the presence of increasing and large number of poor women and elderly people is a cause for big concern. After independence in 1971, the government took several steps to improve the socio economic condition of rural poor female such as SSN program, micro credit program, SME program. The government have been implementing some SSNs programs for different group of people such as children, women, and vulnerable or who are affected by socks.

This paper examines the SSNs programs available for female, whether young or elderly, in Bangladesh. This paper also focuses on whether the existing programs are adequate to tackle the current demographical trend. This paper is organized as follows: Following section describes the current demographic trend of Bangladesh. Then, the section three describes an overview of SSN program of Bangladesh. Section four presents main SSNs programs for women implemented by the government. Then, section five describes the number of beneficiary. Section six presents the amount of benefit whether it sufficient or not. The paper ends with concluding remarks.

\section{Current Demographic Trend}

Demographic structure is going to change rapidly in Bangladesh. Among the total population, ratio of women is increasing day by day due to decrease in infant mortality and maternal mortality rate [6]. In age group $14-64$ years, about 50.7 percent was female and sex ratio was 109.8 percent in
1981. Due to increase in number and life expectancy of this group of people, ratio of female increased to 55.5, 57.9, 59.8, and 62 percent in 1995, 2000, 2005, and 2010, respectively. It is forecasted that it will be 67.7 percent of the total population in 2030 .

On the other hand, age group 65 and above people, for male and female, was 3 percent of the total population in 1982. It increased to 3.3, 3.6, 4.1, and 4.6 percent in 1995 , 2000, 2005, and 2010, respectively. But female rate is increasing more rapidly than male rate as shown in Table 1. Male to female ratio was 123.4 percent in 1981 in age group 65 and above years of people. It falls to 111.9, 103.5, 98.6, and 95.6 percent in 1990, 1995, 2000, and 2010, respectively. It is projected that this ratio will fall to 88.5 percent in 2030 . This means that among the elderly, number of female people is also increasing gradually. Figure 1 and 2 also shows the trend of male and female in age group $(15-65)$ and 65 and above, respectively.

Women are more vulnerable compare to men because of social and cultural tradition [7]. Family tradition is changing by broken joint family to nuclear family [4]. Young male people are migrated to urban area or abroad for earning. As a result, especially female are living alone in the rural areas. In addition, due to large age gap at the time of marriage, husband is died earlier than wife's [8]. Then they become dependent on others. In the age group of below 14, they are also dependent. It can be mentioned that elderly dependency is more expensive than child dependency. Dependent people treated as burden of the society [7]. Generally, most of them are vulnerable and poor. To care for poor and vulnerable women, various kinds of SSNs programs have been implemented by the government and NGOs in the country. In fact, the Government has enhanced at a large scale safety nets as a constitutional commitment and important element of the poverty reduction strategy

Table 1. Trend of Age Group and Sex Ratio

\begin{tabular}{|c|c|c|c|c|c|c|c|c|c|}
\hline & Age $<14$ year & \multicolumn{4}{|c|}{ Age group (14-64) years } & \multicolumn{4}{c|}{ Age group 65+ years } \\
\hline Year & Both Sexes & Both Sexes & Male & Female & Sex Ratio & Both Sexes & Male & Female & Sex Ratio \\
\hline 1981 & 45.7 & 51.0 & 51.8 & 50.7 & 109.8 & 3.0 & 3.2 & 2.8 & 123.4 \\
\hline 1985 & 45.8 & 51.2 & 51.3 & 51.1 & 105.4 & 2.9 & 3.1 & 2.7 & 120.1 \\
\hline 1990 & 44.0 & 52.6 & 52.1 & 53.0 & 100.6 & 3.0 & 3.1 & 2.9 & 111.9 \\
\hline 1995 & 41.5 & 54.7 & 53.9 & 55.5 & 97.6 & 3.3 & 3.3 & 3.2 & 103.5 \\
\hline 2000 & 38.9 & 57.1 & 56.2 & 57.9 & 96.3 & 3.6 & 3.6 & 3.6 & 98.6 \\
\hline 2005 & 36.8 & 58.8 & 57.7 & 59.8 & 94.1 & 4.1 & 4.0 & 4.1 & 96.2 \\
\hline 2010 & 34.3 & 60.6 & 59.2 & 62.0 & 90.6 & 4.6 & 4.6 & 4.5 & 95.6 \\
\hline 2011 & 33.6 & 61.1 & 59.6 & 62.5 & 90.3 & 4.7 & 4.7 & 4.6 & 95.7 \\
\hline 2012 & 33.0 & 61.6 & 60.1 & 63.0 & 90.2 & 4.8 & 4.8 & 4.7 & 95.9 \\
\hline 2013 & 32.3 & 62.1 & 60.6 & 63.5 & 90.2 & 4.9 & 4.9 & 4.8 & 96.1 \\
\hline 2014 & 31.6 & 62.7 & 61.2 & 64.1 & 90.3 & 5.0 & 5.1 & 5.0 & 96.3 \\
\hline 2015 & 30.9 & 63.3 & 61.8 & 64.6 & 90.5 & 5.1 & 5.2 & 5.1 & 96.7 \\
\hline 2020 & 27.7 & 65.9 & 64.9 & 66.9 & 93.1 & 5.8 & 5.8 & 5.8 & 95.6 \\
\hline 2025 & 25.6 & 67.4 & 66.9 & 67.9 & 96.4 & 6.6 & 6.4 & 6.9 & 91.5 \\
\hline 2030 & 24.4 & 67.6 & 67.5 & 67.7 & 98.6 & 8.0 & 7.5 & 8.4 & 88.5 \\
\hline
\end{tabular}

Source: IDB, 2012. Available at www.census.gov/population/international/data 


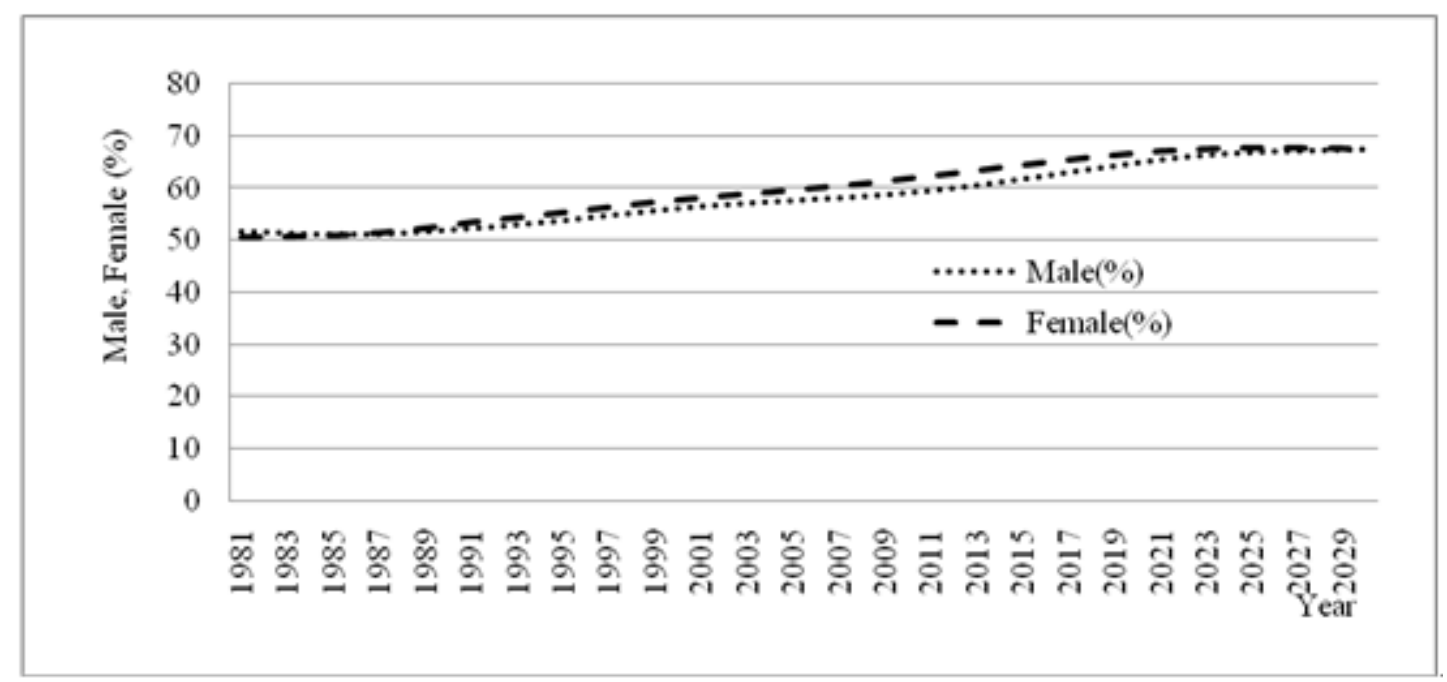

Sources: IDB available fromhttps://www.census.gov/population/international/data/idb/informationGateway.php

Figure 1. Trend of Male and Female in Age group 15-65.

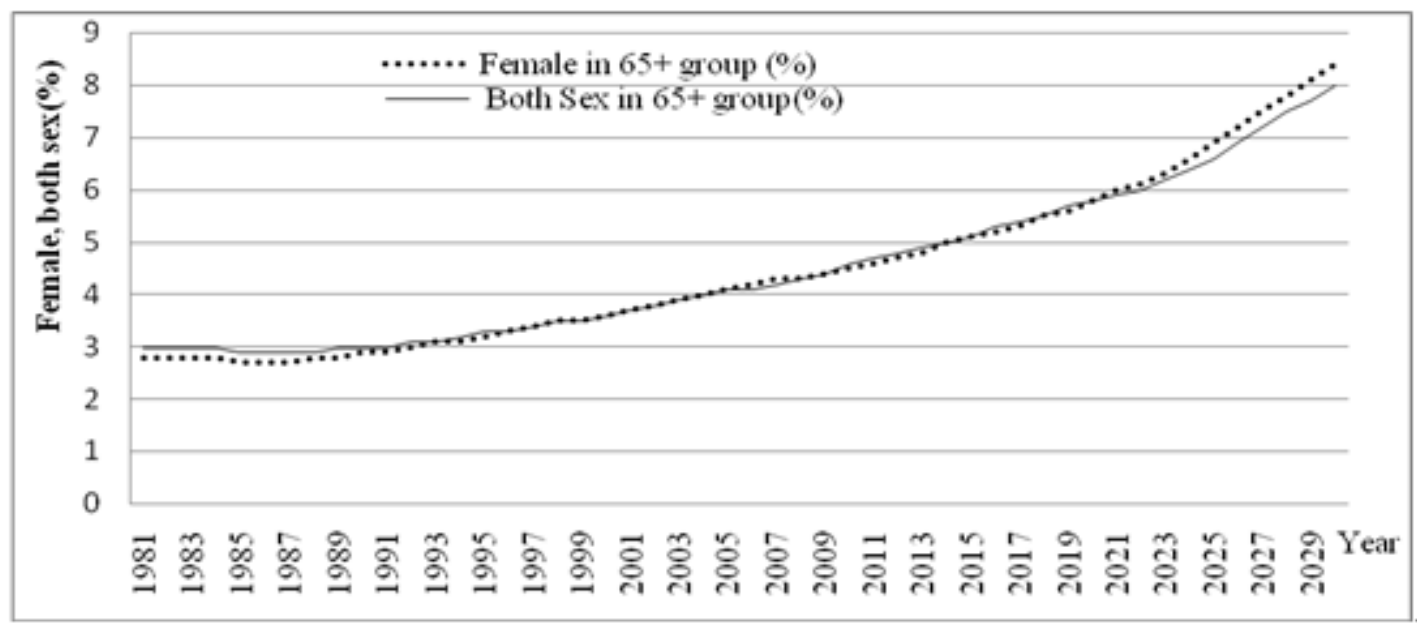

Source: www.census.gov/population/international/data/idb/informationGatew

Figure 2. Trend of Both Sex and Female in Age Group 65+.

\section{Social Safety Nets in Bangladesh: An Overview}

After the independence in 1971, the successive governments have taken various poverty and risk reduction strategies for the poor and vulnerable. In this regard, Bangladesh has made a significant improvement since 1990s. Traditionally, there were two types of public SSNs namely food rationing and post-disaster relief program in Bangladesh. The third type was informal SSNs programs at family and community levels to tackle the demographic and social shocks. The food rationings and post disaster relief stated after independence in 1971. After the famine of 1974, first change occurred in the program and Food For Work (FFW) came out. After that it becomes an independent and large level program focusing on seasonal poverty. At the same time Vulnerable Group Development (VGD) program started with targeting poor women in 1975.Over time, SSNs have become a mainstream social and development concern, especially for women. At the end of 1980s, the next turning point came out was urban and rural rationing as an anti-poverty program. Two new programs which resulted were emerged based on food utilizing women's employment: one Rural Infrastructure Maintenance Program, and another Social Forestry. In addition, in the 1990s, two new SSNs programs were opened. The first one was conditional cash transfer (CCT) focusing on girls' education for a new goal of human development and social empowerment. The second one was an extension of allowance program to cover the elderly and destitute women such as widows and deserted women [9].

In the 1990s, another big development was the institutionalization of post-disaster food security program. After the 1998 flood, Vulnerable Group Feeding (VGF) cards came up and became a basis of safety nets. Current decade has seen as a multi-dimensional assessment of the SSNs programs. Some multi-component programs are Primary Education Stipend Project (PESP), National Nutrition Program (NUP), Rural Employment Opportunities for Public Assets (REOPA), and Employment Guarantee 
Program for Poorest (EGPP).

SSNs programs can be classified based on age groups such as elderly for protection, young for protection and promotion, and children for human resources development and poverty reduction. SSNs programs of Bangladesh give special consideration for the vulnerable groups among the poor. These groups include elderly poor people, widowed or deserted women; disable persons, assistance for acid burnt, assistance for lactating mother, and others.

Rahman, Choudhury, \& Ali [4] mentioned that there were three driving factors in this process of changes: political process that means the welfare responsibilities of the poor have come into centre of the government attention, an erosion social process of informal SSNs due to breaking the joint family system, and realization of development policy makers that SSNs are basic policy tools to a sustainable poverty eradication plan.

The government is firmly committed to mitigate the miseries of the hard-core poor and the deprived community, especially women. Therefore, the government allocates more resources in every year from its non-development budget to implement a number of SSNs programs. While continuing with the on-going programs, the government also adopts new programs that would contribute to the welfare of the poor and also the deprived community. The country has taken a variety of SSNs programs (about 66)such as cash and in kind transfers, micro-credit schemes, and conditional cash transfers for widows, the disabled, blind, orphans, the elderly. Currently, all these programs cover about 13 million poor people of the country though the number of poor is about 45 million [10]. Consequently, these programs can cover only a limited number of poor.

\section{Social Safety Nets for Women in Bangladesh: Program and Benefits}

In Bangladesh most of the people living in rural area are poor. Among them, women are more vulnerable. As a result they have to depend on government direct assistance, relatives or NGOs for their livelihood protection and promotion. The government also has constitutional commitment to protect the poor and vulnerable people. To implement this commitment, the government have been implementing some SSNs programs for different group of people such as child, women, and vulnerable or who are affected by socks.

SSNs programs for women in Bangladesh are found as a big variation in structure and scope over the country, reflecting differences in demographic characteristics, financial capacity, and social and political circumstances. In an attempt to make a broad classification, two "models" of social assistance can be defined: one model is based on age-based social transfer programs and, a second model is based on social transfer programs targets extreme poverty, especially who are under shocks.

Based on age-based social transfer programs model, SSNs programs for the poor women can be classified as female students below 14, age between 14- 64 years, and elderly who are 65 and above ages as shown in Table 2. Previously known as Food For Education project has been replaced in 2002 by the cash-based Primary Education Stipend Program (PESP). It is country wide programs covering about 7.8 million students of primary level. This is for male and female children who are from poor family. This program provides a cash transfer to families that keep children in primary education. The households can received benefits Taka 100 for one children and Taka 125 for two or more children as long as the children attend 85 percent of school days, and obtain at least 40 percent marks in the annual examinations..

Table 2. Social Safety Nets Programs for Women in Bangladesh

\begin{tabular}{|c|c|c|}
\hline SSNs Programs for below 14 age & Qualifying Condition & Benefits \\
\hline Primary Education Stipend Program (PESP) & Attendance and result & Stipend, free tuition and free book \\
\hline $\begin{array}{l}\text { Female Secondary School Assistance Program } \\
\text { (FSSAP) }\end{array}$ & Attendance, examination, marriage & $\begin{array}{l}\text { Stipend, free tuition, and book } \\
\text { allowance, examination fee }\end{array}$ \\
\hline \multicolumn{3}{|l|}{ SSNs Programs for (14-64) age } \\
\hline $\begin{array}{l}\text { Allowance to the Widowed, Deserted and } \\
\text { Destitute Women }\end{array}$ & $\begin{array}{l}\text { Widowed, Deserted and Destitute } \\
\text { Women }\end{array}$ & BDT300 \\
\hline Vulnerable Group Development (VGD) & & $30 \mathrm{~kg}$ rice \\
\hline Food For Works (FFW) & Destitute, widow, landless women & Food transfer \\
\hline $\begin{array}{c}\text { Rural Employment Opportunities for Public } \\
\text { Assets (REOPA) }\end{array}$ & Destitute, widow, landless women & Food, training, (multi-component) \\
\hline $\begin{array}{c}\text { Maternity Allowance for the Poor Lactating } \\
\text { Mothers }\end{array}$ & Poor women & BDT350 \\
\hline $\begin{array}{l}\text { Fund for Rehabilitation of Acid Burnt Women } \\
\text { and the Physically Handicapped }\end{array}$ & $\begin{array}{l}\text { Acid Burnt, the Physically } \\
\text { Handicapped poor women }\end{array}$ & $\begin{array}{c}\text { Treatment, Counselling and } \\
\text { Rehabilitation }\end{array}$ \\
\hline Rural Mother Centre & Rural poor women & Free treatment, medicine \\
\hline \multicolumn{3}{|l|}{ SSNs Programs for $65+$ age } \\
\hline Old Age Allowances & $65+$ Man and women $(50 \%+50 \%)$ & BDT 300 \\
\hline Old Age Home & $65+$ people & Residence and Livelihood support \\
\hline
\end{tabular}


Another program for female student is Female Secondary School Assistance Program (FSSAP). The main object of this program is to increase the number of female students in the secondary school and to control under age marriage. Every female student get fixed stipend per month and they need not pay any tuition or examination fee. However, every female student must fulfill some condition to get benefit such as meeting attendance in the school regularly, up to the marks in the examination and marriage criteria. About 5 million female students receive benefit from this program every year

Some programs are especially for the women (14-64 ages). One of them is Allowances for the Widowed, Deserted and Destitute Women (AWDDW) which was started in 1998. The widowed, deserted, and destitute are more vulnerable in Bangladesh. In social context of Bangladesh, a woman's marital status is important for her endurance and well-being. Once her husband is died or she is separated from her husband, her economic condition becomes uncertain in general among the poor. In fact these groups of women have to readjust the entire basis of her life and work such as whom she lives with, how she earns her livelihood, and others. It is estimated that more than 6 million women are widowed in Bangladesh [7].

Another program is VGD program. The VGD is an important and largest safety net program for women, which is jointly organized and implemented by Ministry of Women and Children's Affairs and Ministry of Food \& Disaster Management with the help of local NGOs. The VGD program exclusively targets poor women. The selected women receive a monthly food ration $(30 \mathrm{~kg}$ rice) per month over a period of 24 months[4]. Although it was introduced as a relief program in the mid-1970s, it has evolved over time to integrate food security with development objectives [11]. Later the development package includes training on income generating activities like livestock, vegetable gardening and awareness-raising on social, legal, health and nutrition issues, and basic literacy. The main objectives of VGD are to assist poor rural women with complementary inputs that will improve their nutrition and enhance their livelihoods and self-reliance, to overcome existing food insecurity, malnutrition, lower social status and poverty. To develop skills of women through training and encourage collecting initial capital for investment through savings are the ultimate goal. Discussion with the associated NGOs in the local area, the VGD selection committee selects women for two years from the destitute and very poor who are physically and mentally sound. To be selected for the program, a household in which the woman belonging should meet at least four of the following criteria: sever food insecurity, i.e. those household members consume less than two full meals in a day, it holds no land or less than 0.15 acres of land, it has very poor housing conditions and it should be headed by a woman and has no mature male income earner.

FFW program provides wheat or rice transfer to enable destitute rural women to improve their economic and social condition. With the in-kind transfers, a complementary package of development services such as health and nutrition education, savings, and support for income earning activities was introduced in 1988. The main objectives of the program are to create food-wage employment during the slack season for construction and maintenance of rural road, river embankments, and irrigation channel. Moreover, this program provides income to the rural poor women when the unemployment rate in rural areas increases.

Rural Employment Opportunities for Public Assets (REOPA) is an employment generated program for women in the rural area such as road maintenance with the help of UNDP. It provides cash for the work. The main focus of this program is to help develop the capacity of the women to run income generating activities successfully.

Maternity Allowance for the Poor Lactating Mothers is a new addition to the list of SSNs in Bangladesh. Under this program, three anti-natal care, cost associated with safe delivery, one post natal care within six weeks of delivery, services for obstetric are provided to poor pregnant mothers [4]. The benefits are given in three steps such as BDT 500 as transport cost to clinic, BDT 500 for referral district hospital, BDT 500 for gift items, and BDT 2000 as cash. In a year, only 100,000 mothers get this benefit supported by WB, UNFPA, and WHO.

Fund for Rehabilitation of Acid Burnt Women and the Physically Handicapped is another program for poor women who are victim of acid crime and physically handicapped. Under this project, medical treatment support, training, and assistance for rehabilitation are provided to the targeted women. About 80,000 women are targeted under this project yearly.

\section{Number of Beneficiaries}

For age group below 14 year, largest program is FSSAP. In the rural area, the numbers of eligible girls who attend school receive this benefit every year. Around 4 million girls get this benefit yearly based on their performance in school. For age group (14-65), largest program is VGF. Though this program is not only for women, priority is given to the rural women headed family. Within this group, one of the largest programs for women is AWDW. Around one million women get benefit every year. Another largest program is VGD program. Every year around 0.75 million women are selected for two year benefit cycle consisting food and skilled training. Only government provided benefit program as social pension for 65 and above people is Old age allowance. Equal number of male and female is selected for the program. Though the total number beneficiary is about 13 million that is shown in Table 3, it is still negligible compare to total people, total poor as well.. 
Table 3. Numbers of Beneficiaries for Some Major Programs (in millions)

\begin{tabular}{|c|c|c|c|c|c|c|c|}
\hline & Age $<14$ & \multicolumn{5}{|c|}{ Beneficiary between age group (14-64) } & Age $65+$ \\
\hline Year & FSSAP & AWDW & Disabled Allowance & VGF & VGD & $\begin{array}{c}\text { Poor Lactating Mothers } \\
\text { Allowance }\end{array}$ & $\begin{array}{c}\text { OAA } \\
(50 \%+50 \%)\end{array}$ \\
\hline 2002 & NA & 0.27 & NA & NA & NA & NA & 0.499 \\
\hline 2003 & NA & 0.50 & NA & NA & NA & NA & 1.00 \\
\hline 2004 & NA & 0.60 & NA & 6.17 & 0.64 & NA & 1.20 \\
\hline 2005 & NA & 0.625 & 0.0104 & 6.30 & 0.64 & NA & 1.50 \\
\hline 2006 & NA & 0.065 & 0.0167 & 7.68 & 0.65 & NA & 1.60 \\
\hline 2007 & 2.90 & 0.075 & 0.02 & 9.58 & 0.63 & 0.045 & 1.70 \\
\hline 2008 & 3.0 & 0.09 & 0.02 & 7.29 & 0.62 & 0.06 & 2.00 \\
\hline 2009 & 3.89 & 0.92 & 0.26 & 11.19 & 0.621 & 0.08 & 2.25 \\
\hline 2010 & 4.00 & 0.92 & 0.286 & 4.85 & 0.75 & 0.088 & 2.48 \\
\hline 2011 & 4.00 & 0.92 & 0.28 & 4.50 & 0.75 & 0.88 & 2.50 \\
\hline 2012 & 4.00 & 0.92 & 0.28 & 4.50 & 0.75 & 0.88 & 2.50 \\
\hline
\end{tabular}

Source: Bangladesh Economic Review (various issues)

According to HIES 2010, 33.9 percent poor is widow or divorced. As 31.5 percent of the population i.e. 45 million people are poor, total number of widow or divorce is about 15 million. Among them, less than 1 million receive benefit financed by the government. Even total number of women beneficiary is not equal to total number of widow. Table 3 shows that FSSAP and VGF have much wider coverage but AWDW and VGD have narrow coverage

In the case of elderly, about 4.8 percent people are elderly of total population (IDB, 2012). According to this estimation, about 7.5 million are elderly people. If we assume that male and female ratio is same, more than 3 million are elderly female. Every year only 2.5 million elderly receive old age allowance. As the beneficiary is selected 50 percent from male and 50 percent from female, only 1.25 million elderly female receive old age allowance which is 40 percent of total old female and 16 percent of total elderly. Iqbal et al., [7] mentioned that about 7 percent of the population is elderly which is equal to 10 million. Begum and Wesumperuma[10] mentioned that only one third of the aged 65 and above people received Old Age Allowance in 2009. However, number of elderly beneficiary or female beneficiary is very narrow proportion. HIES 2010 found that about 24.5 percent of survey household received at least one SSN benefit on an average at national for all program.

\section{Impact of SSN}

Access to secondary education has increased substantially for girls (from 1.1 million in 1991 to 3.9 million in 2005) with an increasing number of girls from disadvantaged or remote areas enrolling. It can be mentioned that between 2000 and 2005 the proportion of beneficiaries from the poorest has increased from 30 to 35 percent. Female student enrolment as a percentage of total enrolment increased from 33 percent in 1991 to 48 percent in 1997 and to about 56 percent in 2005. In comparison, between 1989 and 1991, this proportion increased marginally from about 32 to 33 percent. In addition, increase in Secondary School Certificate pass rates for FSSAP girls from 39 percent in 2001 to 58 percent in 2006 [12]. With the increase of enrolment and pass in examination, household income also increases [13]. Ahmed et al., [14] found that participant of VGD program increased their consumption, savings, and investment. Even this program transfers reduced hardcore poverty by 20 percent. Rahman and Choudhury [13] found that about 75.7 percent VGD beneficiaries have positive impact on their livelihood especially on food consumption (65.6\%) and income generation activities (40.7\%). Pradhan et al., [17] found that the VGD program had protection and promotion effect for the beneficiaries. In addition, the program also has helped to reduce poverty. Mannan [15] found that Old Age Allowance and AWDDW were able to restore the traditional value of taking care of elderly and widow by the household members. This achievement has solved the problem of loneliness of widow and elderly people. Moreover, due to assuring small but regular transfer for widowed and elderly, program benefit increases beneficiaries' income 88 and 74 percent respectively. As a result, independence, dignity, intra household transfers of beneficiaries increase rapidly [13].

\section{Amount of Benefit: Is it Sufficient?}

Though the SSNs have multiple impacts on beneficiary livelihood, the amount of benefit is not optimum. Most of the program benefit such as AWDDW, Old Age Allowance is Taka 300 per month which is equivalent to $\$ 4$. With this benefit, a beneficiary can buy 6 or $7 \mathrm{~kg}$ rice. As living expenses is varied, the Food Poverty Line (FPL) is estimated dividing the country into sixteen strata. The level of benefit is same over the country. As result, same amount of benefit cover the different portion of FPL. Table 4 shows that the level of benefit for OAA and AWDDW is covered from 27 to 32 percent of FPL. It can also be show that this benefit is only 5 percent of per capita GDP. In case of VGD, benefit is given as in-kind, $30 \mathrm{~kg}$ of rice which is about Taka 750 . This benefit covers 68 to 85 percent of FPL. Though inflation rate increased to double, amount of benefit is still same that was set more than five years ago. 
Table 4. Region Wise Food Poverty Line and Amount of Benefit as \% of FPL

\begin{tabular}{|c|c|c|c|}
\hline Stratum & Food Poverty Line (FPL) & OAA or AWDDW benefit as $\%$ of FPL & VGD benefit as $\%$ of FPL \\
\hline 1.Barishal Rural & 982 & 30.55 & 76.37 \\
\hline 3.Chittangong Rural & 1023 & 29.33 & 73.31 \\
\hline 4.Chittangong Urban & 1064 & 28.20 & 70.49 \\
\hline 6. Dhaka Rural & 958 & 31.32 & 78.29 \\
\hline 7. Dhaka Urban & 1018 & 29.47 & 73.67 \\
\hline 8. Dhaka SMA & 1089 & 27.55 & 68.87 \\
\hline 12.Rajshahi Rural & 957 & 31.35 & 78.37 \\
\hline 13.Rajshahi Urban & 987 & 30.40 & 75.99 \\
\hline 14.Rajshahi SMA & 931 & 32.22 & 80.56 \\
\hline 15.Sylhet Rural & 953 & 31.48 & 78.70 \\
\hline 16.Sylhet Urban & 992 & 30.24 & 75.60 \\
\hline
\end{tabular}

Note: SMA = Sami Metropolitan Area,

\section{Conclusions}

As a digester prone and over populated country, protecting rural poor women in time of natural disaster or crisis, balancing social pressure due to change in demographic structure especially elderly, and helping dependent people like children, widowed or divorced are main challenging issues. Santos et al. ([16] showed that more than half of the households experienced one or more shocks over a year recall period and the average number of shocks across all households was 1.6. Rural households are more likely to experience shocks and more vulnerable. Number can vary depending on shocks occurrences which is difficult to predict earlier. Sometime, from six month to one year elapse from time the crisis occurred to extend the assistance. This situation can make the suffering for long, even for ever. So assistance should be provided immediately after affecting shocks

Demographical trend suggests a rapid increase in female in different age groups. Even the percentage of elderly in the population is predicted to double by 2030 . Considering all factors, number of beneficiary should be increased especially for OAA. OAA can be extended as universal social pension like Nepal, Maldives where benefit is offered for all eligible elderly. For universal pension of qualified elderly at allowance Taka 300 per month, about 0.34 percent of GDP will be required. It can be mentioned that all female elderly can be covered with the same amount of allocation as total number of female elderly is near about half of total elderly. Amount of benefit covers only a small portion of FPL that between 27 to 32 percent and it costs about 0.13 percent of GDP. If the benefit amount rises to double, only 0.26 percent of GDP will be required. Monthly allowance for widow and destitute women, and lactating mother should be raised at least double and revised yearly based on inflation. As SSNs have protection and promotion effects, beneficiary will be independent in financial affairs and decision making if the government strengthen the link between benefit, other social services such as health, education, motivation, employment opportunity. The benefit in SSNs expenditure for women is large because female members are more responsible in every stage of family life in every family. As there is high possibility to loss the support due to the death of husband, abandoned or divorce, instable earning pattern normally found among the female. Proper assistance need to be design so that they can get support immediately and for longer time.

\section{REFERENCES}

[1] A.Vlachantoni, J. Falkingham. Gender and Old-Age Pension Protection in Asia, in Social Protection for Older Persons, S.W. Handayani and B. Babajanian, Editors. Asian DevelopmentBank. 120-134, 2012.

[2] R. Jahan. Women in Bangladesh, in Women Cross-Culturally: Change and Challenge, R. Rohrlich-Leaveitt, Editor. World Anthropology, 5-30, 1975.

[3] M. Siddique. Gender issues in poverty alleviation: a case study of Bangladesh, International Journal of Social Economics, Vol. 25, No. 6, 1095-1111, 1998.

[4] H.Z. Rahman, L.A. Choudhury, K.S. Ali. Social Safety Nets in Bangladesh. Review of Issues and Analytical Inventory. Dhaka: Power and Participation Research Centre, Vol. 1. 2011. 
[5] BBS, Primary Report on Household Income \& Expenditure Survey (HIES)-2010, Bangladesh Bureau of Statistics: Dhaka, Bangladesh, 2011.

[6] United Nations. Social Safety Nets for Women Economic Social Commission for Asia and the Pacific. United Nations, 2003,

[7] M. A. Iqbal, T. I. Khan, T.Tahsina.Macroeconomic Implications of Social Safety Nets in the Context of Bangladesh, Centre for Policy Dialogue (CPD), 2008.

[8] S.S. Jesmin, S.R. Ingman. Social Supports for Older Adults in Bangladesh, The Journal of Aging in Emerging Economies, 69-79, 2011.

[9] A. Barrientos, M. Niño-Zarazúa, M. Maitrot. Social Assistance in Developing Countries Database Version 5.0, Chronic Poverty Research Centre, 2010.

[10] S. Begum, D. Wesumperuma. Overview of the Old Age Allowance Programme in Bangladesh, in Social Protection for Older Persons, S.W. Handayani and B. Babajanian, Editors, ADB, 187-213, 2012.

[11] S.S. Ahmed. Social Safety Nets in Bangladesh. Background Paper for Bangladesh Poverty Assessment. Mimeo. World Bank, Washington DC, 2007.
[12] A.T. Schurmann. Review of the Bangladesh Female Secondary School Stipend Project Using a Social Exclusion Framework, Journal of health, population, and nutrition, Vol.27, No. 4, 505, 2009.

[13] H.Z. Rahman, L.A. Choudhury. Social Safey Nets in Bangladesh, Power and Participation Research Centre (PPRC),Dhaka, 2012.

[14] A.U. Ahmed, A. R. Quisumbing, M.Nasreen, J. F. Hoddinott, E. Bryan. Comparing food and cash transfers to the ultra poor in Bangladesh. Washington, DC: International Food Policy Research Institute, 2009.

[15] M.A Mannan. Safety Net Program in Bangladesh: Assessing the Perormance of Selected Programs. Bangladesh Institute of Development Studies (BIDS), Dhaka, 2010.

[16] I. Santos,I.Sharif,H. Z. Rahman, H. Zaman. How do the poor cope with shocks in Bangladesh? Evidence from survey data, World Bank Policy Research Working Paper Series, No.5410, 2011.

[17] M. A. H Pradhan, J. Sulaiman, \& S. Mohd. An analysis of the millennium development goal 1: The case of Bangladesh. New Zealand Economic Papers,Vol 48, No.3, 269-284, 2014. 